\title{
A BIM-Based Value for Money Assessment in Public-Private Partnership: An Overall Review
}

\author{
Guoqian Ren ${ }^{1, * \mathbb{D}}$, Haijiang $\mathrm{Li}^{2, *}$ and Jisong Zhang ${ }^{3, *}$ \\ 1 BIM for Smart Engineering Centre, Cardiff University, 52 the Parade, Cardiff CF24 3AB, Wales, UK \\ 2 Cardiff School of Engineering, Cardiff University, Queen's Buildings, Cardiff CF24 3AA, Wales, UK \\ 3 School of Civil Engineering, Dalian Jiaotong University, Dalian 116028, Liaoning, China \\ * Correspondence: RenG@cardiff.ac.uk (G.R.); Lih@cardiff.ac.uk (H.L.); jisong_z@hotmail.com (J.Z.)
}

Received: 4 August 2020; Accepted: 11 September 2020; Published: 17 September 2020

\begin{abstract}
Public-private partnerships (PPPs) have proliferated and adapted to public development in recent decades; within it, the value for money (VfM) assessment defines the feasibility of the project procurement model as one of the essential components of PPP. However, evaluating the VfM in PPPs remains problematic. Given concerns about PPP profitability, a more integrated VfM evaluation is urgently needed to manage multiple indicators along the project lifecycle. Building information management (BIM), popular in architecture, engineering, and construction, provides resources that could support the VfM to a great extent. This paper uses a review approach to identify the current issues that are affecting VfM assessments and suggests that BIM, functioning throughout the PPP lifecycle, could support decision-making in VfM processes in order to satisfy service targets.
\end{abstract}

Keywords: public-private partnership; infrastructure procurement; value for money; building information management

\section{Introduction}

The public-private partnerships (PPP) model has been well-implemented for project concessions by developing countries to replace the traditional procurement model. In general, PPP remain popular and continue to be implemented into infrastructure project plans [1]. PPP provide the initial life cycle ambitions in a strategic plan when there is substantial concern about the value for money (VfM). Holistic means are required to provide better VfM as a fundamental part of PPP model implementation [2]. The VfM assessment conducted in the initial stages of PPP plays a crucial role in financial evaluation, which informs the decision on whether a PPP model is viable or not. However, the current VfM process draws from multi-sources with second-hand data, and decisions are made without an adequate information exchange between the involved parties [3]. The consequent lack of information makes it difficult for the public sector to evaluate whether the cost is commensurate with the benefits and risks [4]. Reports [5] by the European PPP Expertise Centre (EPEC) indicated that the capability and critical drivers of the consultative machinery used in a large number of PPP projects are questionable, lacking reliable information to support VfM assessments. The PPP model does not "bring extra money" in many cases and has failed to meet the risk transfer targets in many cases [6]. Although the VfM assessment in some projects is recognised to be well-completed, launching the automation and intelligence of the assessment itself still has its potential; to stress, the whole life cycle benefits to a greater extent. However, the existing VfM assessments were made without the support of real-time engineering data [7].

In the public procurement workflow, building information management (BIM) has the potential for clients, mainly governments, to become involved in project management. The BIM models have the potential to function as an inspection aid but are more applicable to management. Currently, 
BIM-related technologies are used to build integrated management systems in infrastructure projects. Love et al. [8] pointed out that BIM has not been extensively used to deliver measurable estimates. There is a possibility of "future-proofing" PPP projects using performance-based asset information provided by the BIM. Toward achieving this concept based on the VfM assessment, the relevant research and documents are reviewed to answer the following questions:

(1) Do the current VfM assessments meet the requirement of this concept?

(2) To what extent can the VfM contents be related to the BIM, and is it possible to build a BIM-supported VfM assessment?

Based on the previous research work relating to BIM and its value for a money assessment, this paper aims to address these research questions. Some contents in this article are referenced by previous PhD research works [9]. To conduct a comprehensive review of this topic, the following research is reviewed:

(1) Relevant literature focused on PPP performances in order to summarise the most important indicators of procurement.

(2) VfM content by summarising the guidance of both quantitative and qualitative assessments.

(3) PPP policies and legal frameworks in different countries, as well as in-depth investigations from the published PPP project documents in China to indicate the VfM application status.

(4) BIM-based research aligned with the VfM and other key performance indicators to further analyse the emerging operational framework.

The core objective of this paper is to identify the VfM application status and align it with the BIM-based approach. The review process of the VfM and BIM are conducted separately and then synthesised to explain that the performance requirement of VfM can be supported using the BIM as the necessary information query and function platform. A decision-making framework of BIM-based $\mathrm{VfM}$ is discussed in the conclusion.

The contents of this paper are organised as follows: A brief explanation of the review methodology is given in Section 2. Section 3 presents a comprehensive review of the VfM. Specifically, Section 3.1 presents the main statistical analysis of the literature, and Section 3.2 reviews the VfM implementation status from a legal and project practice perspective. Section 3.3 presents the VfM contents. The BIM-based study aligned with the VfM content is given in Section 4. Section 5 provides a discussion and research gap identification. A roadmap for BIM-supported VfM assessment is proposed in Section 6, and the conclusion is given in Section 7.

\section{Methodology}

In this paper, it seeks to stress that the BIM could provide the potential support to VfM assessments. For achieving that, this review-based methodology can be divided into two parts, which respectively concern the VfM and BIM. In order to produce a comprehensive review of the subject of the VfM, the review has the following components:

- Research Publications: The papers on PPP were mainly sourced from construction and public procurement domain journals using the ScienceDirect and Scopus search engines. The information was collected via systematic literature research using keywords and content criteria. The results revealed that the assessment indicators in VfM were aligned with the other key indicators, such as key performance indicators (KPI).

- Published Guidance and Documentation: This included the status of overseas VfM-related methodology published by the World Bank Group and procurement project documents in the Chinese financial sector. The documentation explained that VfM was inadequately catered for in current project practices. More specifically, procurement documentation from the Ministry of Finance of the People's Republic of China was collected. The documents consisted of VfM reports on transportation, urban housing, education, culture, nursing, and municipal engineering from Chinese PPP demonstration projects, which heavily reflected the practical application of VfM. 
- Procedures and Contents: Current representative legal VfM guidance was sourced from the related national and international governing bodies to express the requirements of $\mathrm{VfM}$ contents (e.g., British VfM assessment guidance, US Federal Highway Administration Guidebook for VfM assessment, and Chinese PPP VfM guidance). The selection of related guidance was gathered at various conferences and events, along with the information from literature and industry reports.

The following research used the same academic sources to review BIM:

- Research Publications: The intersection of BIM and project quantitative and qualitative management aspects corresponding to the contents of the VfM were supplemented with transferable construction contents. A combined quantitative approach was taken to classify further and analyse the literature presented. In addition, the alignment between BIM and the ontological approach was also reviewed as a new research methodology for knowledgebase development.

- Tools and Software: The implementation of BIM for multiple project purposes corresponded to the VfM content.

A combined discussion further classified and analysed the BIM-related literature to identify the implementation domain of BIM research and how it could benefit VfM assessment in PPP projects.

\section{Overview of Value for Money Assessment}

\subsection{PPP Literature Review and VfM}

There is a significant body of literature exploring the topic of PPP application. To get the important factors of public procurement and explore the VfM-related factors, the following search criterion was devised in both the Science Direct and Scopus search engines: (public-private partnership OR PPP) AND (infrastructure OR Construction) AND (important factor OR Success factor) AND (Value for money assessment OR VfM) AND PUBYEAR AFT 2006 AND PUBYEAR BEF 2017 AND (LIMIT-TO (LANGUAGE, "English")) AND (LIMIT TO (SRCTYPE, "j") within (Title OR Keyword). Based on the criterion, Table 1 shows the removal of irrelevant literature types, leaving only journal articles. Literature rated three to five remained, resulting in a final literature volume of 187 papers that only concerned PPP infrastructure performances. A combined quantitative and qualitative analysis was performed to classify the literature further.

Table 1. Descriptions of rating criteria to remove irrelevant research articles. PPP: public-private partnerships.

\begin{tabular}{ll}
\hline Rating & Description of Criterion to Remove Not-Related Literature \\
\hline 5 & Literature focus on the important factors in PPP infrastructure projects \\
4 & Literature focus on investigating the PPP infrastructure status from the procurement level \\
3 & Generalised nonspecific work on PPP infrastructure research \\
2 & Literature relates to public procurement on infrastructure but not specifically relates to the \\
& PPP model \\
1 & Irrelevant literature that does not concern the infrastructure type of work nor PPP \\
\hline
\end{tabular}

Eighty-five of the selected research papers referred to multiple PPP infrastructure projects. The remaining articles were concerned with different construction types. As shown in Figure 1, over $23 \%$ of the road and tunnel work was conducted using a PPP procurement model, which was a relatively low proportion. With respect to the research outcomes, the literature that was focused on "investigation and analysis" produced a high volume of work; there were 72 different infrastructure subjects. There was also extensive works focusing on the most common research themes, which were project case studies, methodology development, framework, and review approaches. 


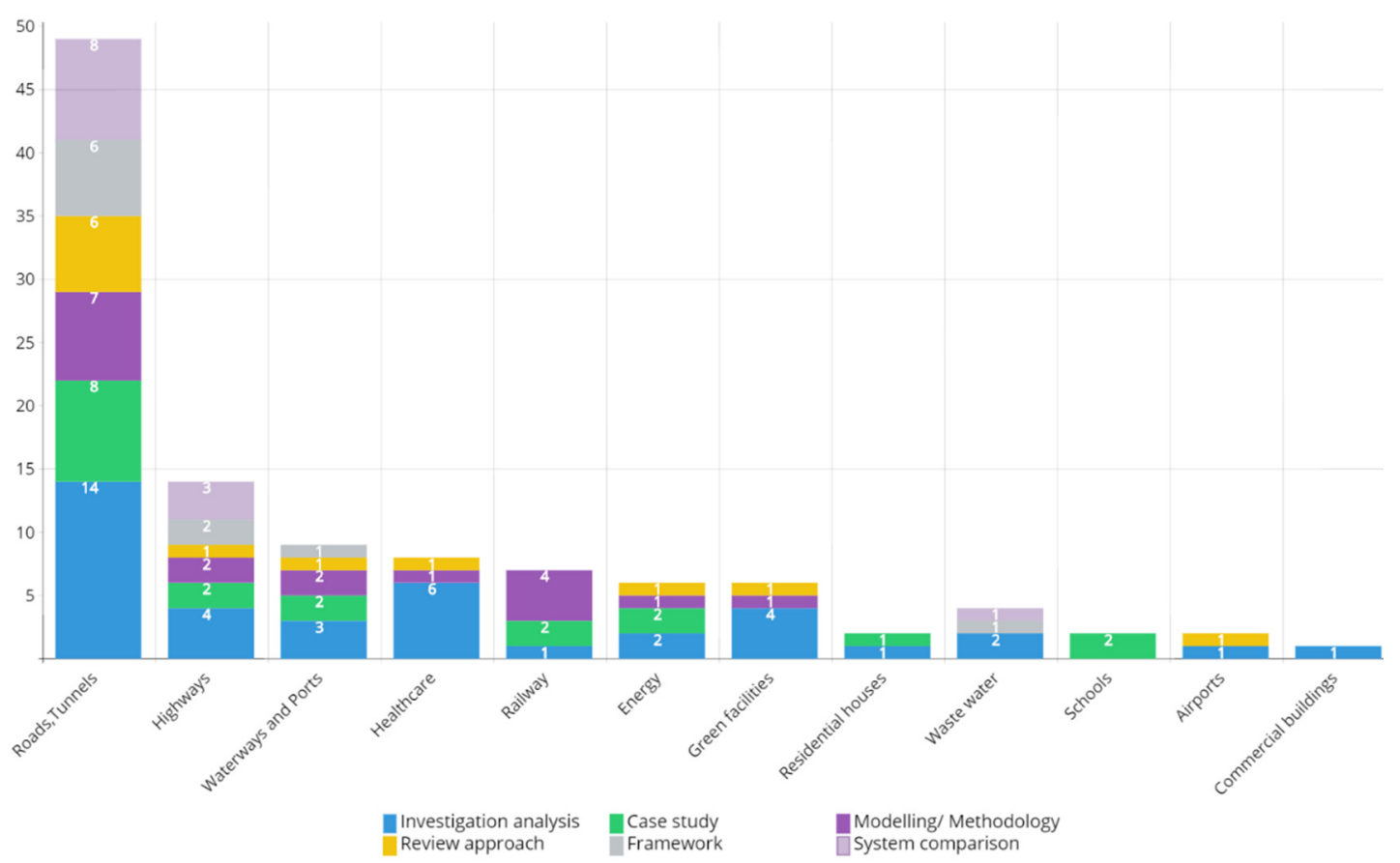

Figure 1. Distribution of public-private partnerships (PPP) infrastructure publications by research outcomes and industry sector. Source: selected literature.

Figure 2 represents the distribution of the research articles that stressed different important factors or dimensions in the PPP infrastructure. Literature concerning "risk factors" (35), which referred to risk indication and allocation schema, "performance factors" (32) related to project performance measurement, and "critical success factors" (CSF) were found in high proportions. Other emerging areas included the leveraging of business models to stress the PPP implementation status (21) and relationship management (20). Specifically, with respect to finances, the underdevelopment of the VfM assessment was indicated (4). This was due to most literature on financial management not involving the structure or official body defined in VfM nor any to links to measurement issues. The papers refer to VfM assessments that are mainly investigation and analysis and literature review-based research. For example, Henjewele et al. [10] proposed to use empirical studies to investigate the variations in PPP transport sectors that influenced the VfM assessment and found that the current assessment was often carried out with considerable uncertainty in costs estimates and requirements.
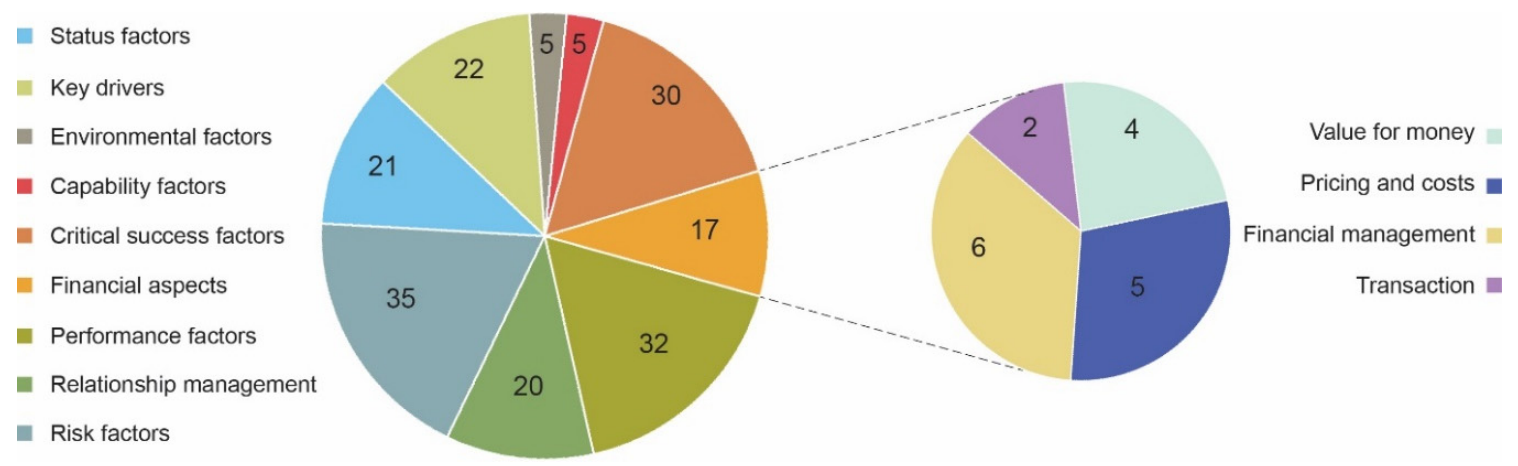

Figure 2. Distribution of important factors/dimensions addressed in PPP infrastructure publications. Source: selected literature. 
Since there were differences in the levels of detail given in the papers selected, there was some degree of overlap and "merging" of indicators. There were articles in the selected papers that used a five-point Likert rating scale to assess important factors from one to five. In this article, the papers that contained specific mean values of important factors are presented in Table 2. To classify indicators along with procurement stages, the table lists the subset of internal procurement indicators that refer to in the World Bank's typical PPP process, which goes through the contract "pipeline" until the final implementation [11]. The external indices were not included.

Table 2. Overview of PPP project internal indicators in recent research articles with the mean values of importance. Source: selected literature. The classification catalogue is based on the World Bank Group PPP reports.

\begin{tabular}{|c|c|c|c|c|c|c|c|c|c|c|c|c|}
\hline Internal Indicators & [12] & [12] & [13] & [14] & [15] & [16] & [17] & [18] & [18] & [19] & [20] & Average Value \\
\hline \multicolumn{13}{|l|}{ Screen as PPP } \\
\hline $\begin{array}{l}\text { The methodology of } \\
\text { project selection }\end{array}$ & & & 3.40 & & 3.10 & 4.06 & 4.33 & & & 3.69 & 3.97 & 3.76 \\
\hline $\begin{array}{l}\text { Project } \\
\text { plan/programming }\end{array}$ & & & & 3.16 & 4.24 & & 4.42 & & & & & 3.94 \\
\hline \multicolumn{13}{|l|}{ Structure PPP } \\
\hline $\begin{array}{l}\text { Risk/Responsibility } \\
\text { allocation }\end{array}$ & 4.34 & 3.89 & 3.77 & & & 3.98 & 3.99 & & & & & 4.00 \\
\hline \multicolumn{13}{|l|}{ Appraise PPP } \\
\hline Cost/benefits assessment & 3.79 & 3.61 & & 4.25 & 4.51 & & 4.00 & & & 3.57 & 4.81 & 4.08 \\
\hline $\begin{array}{l}\text { Finance/resources } \\
\text { availability }\end{array}$ & & & 4.25 & & 2.90 & & 4.37 & & & & & 3.84 \\
\hline Finance closure & & & 3.02 & & & & & 3.69 & 4.00 & 3.74 & & 3.61 \\
\hline Technical innovation & 3.62 & 3.72 & & & 4.40 & & 3.88 & 3.38 & 4.25 & & 4.06 & 3.90 \\
\hline $\begin{array}{l}\text { Delay in approval and } \\
\text { payment }\end{array}$ & & & 3.65 & & 4.07 & & & & & 3.40 & 4.35 & 3.87 \\
\hline \multicolumn{13}{|l|}{ Design and Manage PPP } \\
\hline Tender and competition & 3.81 & 3.70 & & 3.06 & & & & 4.17 & 3.82 & 3.35 & & 3.65 \\
\hline $\begin{array}{l}\text { Requirements of } \\
\text { stakeholders }\end{array}$ & 4.04 & & 3.33 & 3.66 & 2.92 & 3.70 & 4.33 & 3.15 & 4.00 & & 4.55 & 3.74 \\
\hline $\begin{array}{l}\text { Brief and contract } \\
\text { documents }\end{array}$ & & 3.75 & & 3.63 & & 3.91 & 4.34 & & & 3.48 & 4.61 & 3.95 \\
\hline $\begin{array}{l}\text { Transparent procurement } \\
\text { process }\end{array}$ & 4.00 & 3.98 & & & & & 4.00 & & & 3.69 & & 3.92 \\
\hline $\begin{array}{l}\text { Building a } \\
\text { team/Competent team }\end{array}$ & & & & & 3.07 & 4.06 & 4.30 & & & & 4.35 & 3.95 \\
\hline Change in contract & & & 3.38 & & 3.06 & & 4.24 & 3.54 & 4.13 & 3.40 & 4.29 & 3.72 \\
\hline \multicolumn{13}{|c|}{ Design \& Construction and Completion } \\
\hline Site construction safety & & & 4.08 & & 3.13 & & & & & & 4.65 & 3.95 \\
\hline Site availability & & & 2.50 & & & & & 3.92 & 4.00 & 3.43 & & 3.46 \\
\hline $\begin{array}{l}\text { Design } \\
\text { deficiency/Buildability }\end{array}$ & & & 3.17 & & & & & & & & 4.74 & 3.96 \\
\hline Workmanship/Complexity & & & 3.15 & & & & 4.17 & & & & & 3.66 \\
\hline Completion/Time delay & & & 4.21 & & 4.57 & 3.04 & & 3.54 & 4.44 & 3.49 & & 3.88 \\
\hline Material/Labour/Equipment & & & 3.28 & & 4.36 & & 3.64 & 4.23 & 4.47 & 3.41 & 4.74 & 4.02 \\
\hline Construction cost overrun & & & 4.08 & & & & & 4.15 & 4.29 & & 4.65 & 4.29 \\
\hline \multicolumn{13}{|l|}{$\begin{array}{l}\text { Operation and Market } \\
\text { Risk }\end{array}$} \\
\hline Market interest & 4.15 & 3.54 & 3.42 & 3.00 & 4.07 & & & & & 3.60 & & 3.63 \\
\hline Operation cost & & & 3.29 & & 4.43 & & & 4.15 & 3.94 & 3.54 & & 3.87 \\
\hline Operation performance & & & 3.23 & & & & & 3.73 & 4.27 & & & 3.74 \\
\hline Residual assets & & & 2.48 & & & & & & & 2.70 & & 2.59 \\
\hline $\begin{array}{l}\text { Operation strategy } \\
\text { change }\end{array}$ & & & 2.40 & & 4.22 & & & 3.38 & 3.76 & 3.49 & & 3.45 \\
\hline
\end{tabular}


Through the average of the mean values in procurement workflow, it can be seen that, in the PPP project stages, "risk and responsibility allocation" and "procurement assessment of cost and benefits" in the preconstruction phase are regarded as very important and are focused upon in the literature. These two aspects are vital constituents of the early stage VfM process, which indicate that the VfM influences the success of a PPP project [21]. The performance "technical innovation", "brief and contract documents", and "market interest" are also overlapped with the performance indicators in the VfM qualitative assessment. This can be seen in Table 3 in the following section. Moreover, in the project implementation phase, the literature reveals the crucial nature of construction management, especially "the management of material and available resources" and of cost-related factors during the procurement phase. Based on the definition of quantitative assessment in different nations, these cost-related aspects also can be regarded as the fundamental constitution of the VfM; these contents are discussed in the following quantitative assessment section.

VfM is currently defined as a comprehensive assessment approach. Its performance contents usually overlap with other essential project factors. VfM is even used to justify the feasibility of using a PPP model. It is also a structural means to verify income based on project strategies. VfM should provide a hospitable environment within which to perform performance monitoring so that long-term targets can be achieved. However, the current research articles that stress assessment lack further development. Very few pieces of literature consider the entire process when aiming to strengthen the assessment and develop the methodology to specify procedures.

\subsection{VfM Assessment Application Status}

A PPP contract usually runs 30 to 50 years or more, which is longer than traditional procurement arrangements, and it can generate more project uncertainties within the lifecycle. VfM is used to determine whether a project is suitable for the PPP model and, in fact, could be defined as an entire lifecycle assessment [22]. Using data from the World Bank Group and Public-Private Infrastructure Advisory Facility (PPIAF), Table 3 shows the various VfM approaches commonly used in different regions. However, aspects of the practical operation were insufficiently considered [23]. Countries have begun to set up a specific methodology that concerns VfM but lacks supporting information from engineering aspects concerning implementation.

Table 3. Value for money (VfM) application status in major PPP countries [23].

\begin{tabular}{|c|c|c|c|}
\hline Country & VfM Application Status & PPP Legal Framework & VfM Toolkit \\
\hline Turkey & $\begin{array}{c}\text { No specific methodology } \\
\text { developed }\end{array}$ & No & No \\
\hline China & Specific methodology developed & $\begin{array}{l}\text { Guidelines for the Operation of } \\
\text { Public-Private Partnership (trial) }\end{array}$ & $\begin{array}{l}\text { Government and social capital } \\
\text { cooperation project value for money } \\
\text { assessment guidelines }\end{array}$ \\
\hline Indonesia & $\begin{array}{l}\text { No specific methodology } \\
\text { developed }\end{array}$ & $\begin{array}{l}\text { The Presidential Regulation No. } \\
38 \text { of 2015; The Ministry of } \\
\text { National Development } \\
\text { Planning/National Development } \\
\text { Planning Agency (BAPPENAS) } \\
\text { Regulation No. } 4 \text { of 2015; The } \\
\text { Government Goods and Services } \\
\text { Procurement Policy (LKPP) } \\
\text { Regulation No. } 19 \text { of } 2015\end{array}$ & No \\
\hline Brazil & $\begin{array}{l}\text { No specific methodology } \\
\text { developed }\end{array}$ & $\begin{array}{l}\text { The General Law for } \\
\text { Public-Private Partnerships }\end{array}$ & $\begin{array}{l}\text { Public-Private Partnership in Roads } \\
\text { and Highways (P3 Toolkit, } 2013\end{array}$ \\
\hline India & Specific methodology developed & $\begin{array}{l}\text { General Financial Rules; Model } \\
\text { RFQ (Request for quote) and } \\
\text { RFP (Request for proposal); } \\
\text { Model concession agreements; }\end{array}$ & PPP Structuring Toolkit \\
\hline
\end{tabular}


Table 3. Cont.

\begin{tabular}{|c|c|c|c|}
\hline Country & VfM Application Status & PPP Legal Framework & VfM Toolkit \\
\hline UK & Specific methodology developed & Public procurement law & $\begin{array}{l}\text { Value for money assessment } \\
\text { guidance; } \\
\text { Assessing value for money; } \\
\text { CIPFA Toolkit }\end{array}$ \\
\hline France & Specific methodology developed & $\begin{array}{l}\text { PPP and concession law (two } \\
\text { regimes) }\end{array}$ & $\begin{array}{l}\text { MAPPP guidance template for the } \\
\text { Preliminary Assessment; } \\
\text { Reference guide for a financial } \\
\text { model for the Preliminary } \\
\text { Assessment }\end{array}$ \\
\hline USA & Specific methodology developed & $\begin{array}{c}\text { Different PPP laws in different } \\
\text { states }\end{array}$ & $\begin{array}{l}\text { Value for money analysis for P3s; } \\
\text { P3-VALUE Analytical Tool }\end{array}$ \\
\hline Chile & $\begin{array}{c}\text { No specific methodology } \\
\text { developed }\end{array}$ & $\begin{array}{l}\text { Concessions Law and } \\
\text { regulations }\end{array}$ & No \\
\hline South Africa & Specific methodology developed & $\begin{array}{l}\text { National Treasury PPP Practice } \\
\text { Note }\end{array}$ & $\begin{array}{c}\text { Public-Private Partnership Manual, } \\
\text { South Africa }\end{array}$ \\
\hline Canada & Specific methodology developed & P3s guidance for public sponsors & $\begin{array}{l}\text { PPP public sector value for money } \\
\text { guidance }\end{array}$ \\
\hline Australia & Specific methodology developed & National PPP Policy Framework & Value for money guidance \\
\hline
\end{tabular}

To stress the application situation, this paper also sourced the published VfM reports from the Ministry of Finance of China. The Chinese government has been embarking on an ambitious programme of investments on large urban municipal engineering projects. Until April 2018, the Ministry of Finance of China already published four batches of demonstration projects, with the total number 1093.

Based on the VfM performance in the engineering project domain (e.g., transportation, urban housing, education, culture, nursing, and municipal engineering), using the PPP project library of the China Public-Private Partnerships Centre, the VfM reports of each project were collected and analysed. As shown in Figure 3, a considerable number of projects did not provide an appropriate quantitative assessment. This indicates that the VfM, which is regarded as essential, still lacks completeness with respect to implementation. As for the project with the VfM report document, the author also investigated the report in detail and determined that the data processing was inaccurate. The presentation of the qualitative assessment, its content, and how managers scored the related factors were also problematic in most PPP projects. More detailed explanations and measurement approaches are required to enhance the level of the quantitative performance. The qualitative process was conducted in an excessively simple form, while the quantitative method was frequently abrogated or postponed due to feasibility issues [24].

To emphasise the content of the VfM, the following section contains both qualitative and quantitative features sourced mainly from VfM guidance in the UK, the USA, and China. The following sections introduce the BIM concept (Section 4) and how BIM-based information exchange and management could be absorbed into the VfM structure. 


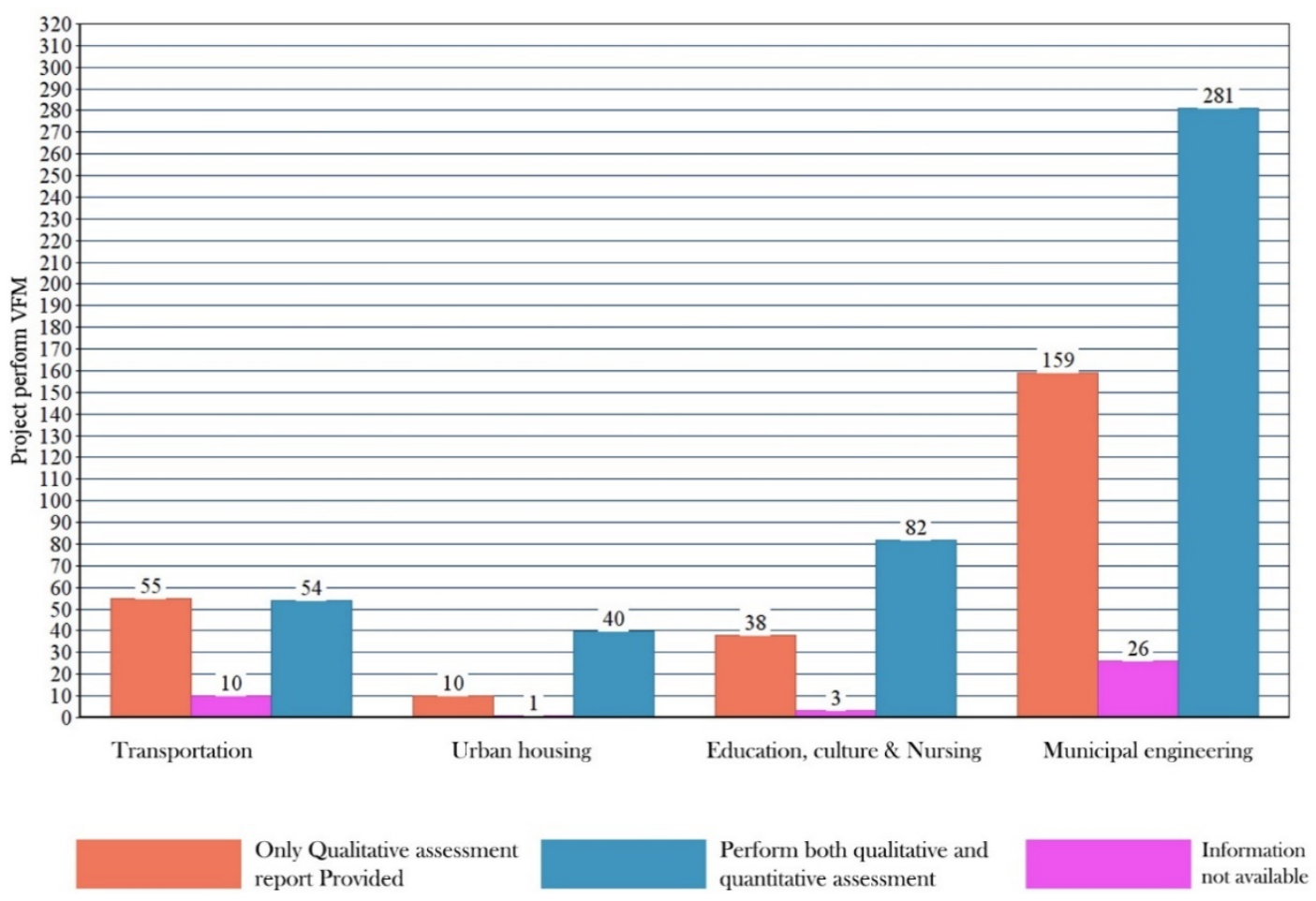

Figure 3. Value for money (VfM) implementation status in China. Source: published PPP project documents from the Ministry of Finance of China.

\subsection{Review of VfM Assessment Contents}

The definitions of VfM given by the UK Government and the World Bank Group describe the optimum combination of whole-of-life costs and quality [25]. The criteria specify that, among other factors, business incentives within the procurement process could be integrated into a performance benchmarking process, as an initial reference [26]. As things currently stand, the VfM process is a subjective matter. There are now toolkits and measurement lists to provide guidance on PPP in comparing the actual outcomes of alternative procurement options. In the appraising and structuring stage of PPP, the analysis of VfM is made under the evaluation directory, with project feasibility, commercial viability, and risk indication and allocation. Compared with other assessment processes in PPP, these drivers of the VfM include most of the elements mentioned above, such as the project feasibility and commercial viability. This makes the VfM process more comprehensive. The VfM does not merely rely upon the whole life costs of the assets, which are regarded as an early stage quantitative assessment, but it is also viewed in terms of the project's ability to achieve a high level of performance. Thus, the VfM is judged by assessing every aspect and element of the project quality [25].

Qualitative and quantitative assessments are applied during a typical workflow of the PPP process, as shown in Figure 4. In the project's decision-making phase, assessing the VfM could simulate the competitiveness that can inform and prompt decision-making around traditional and social capital. Evaluating project construction may become more practical due to the certainty of data management. Thus, the VfM process becomes not only a decision-making tool but, also, a means by which to evaluate the project performance throughout its lifecycle. 


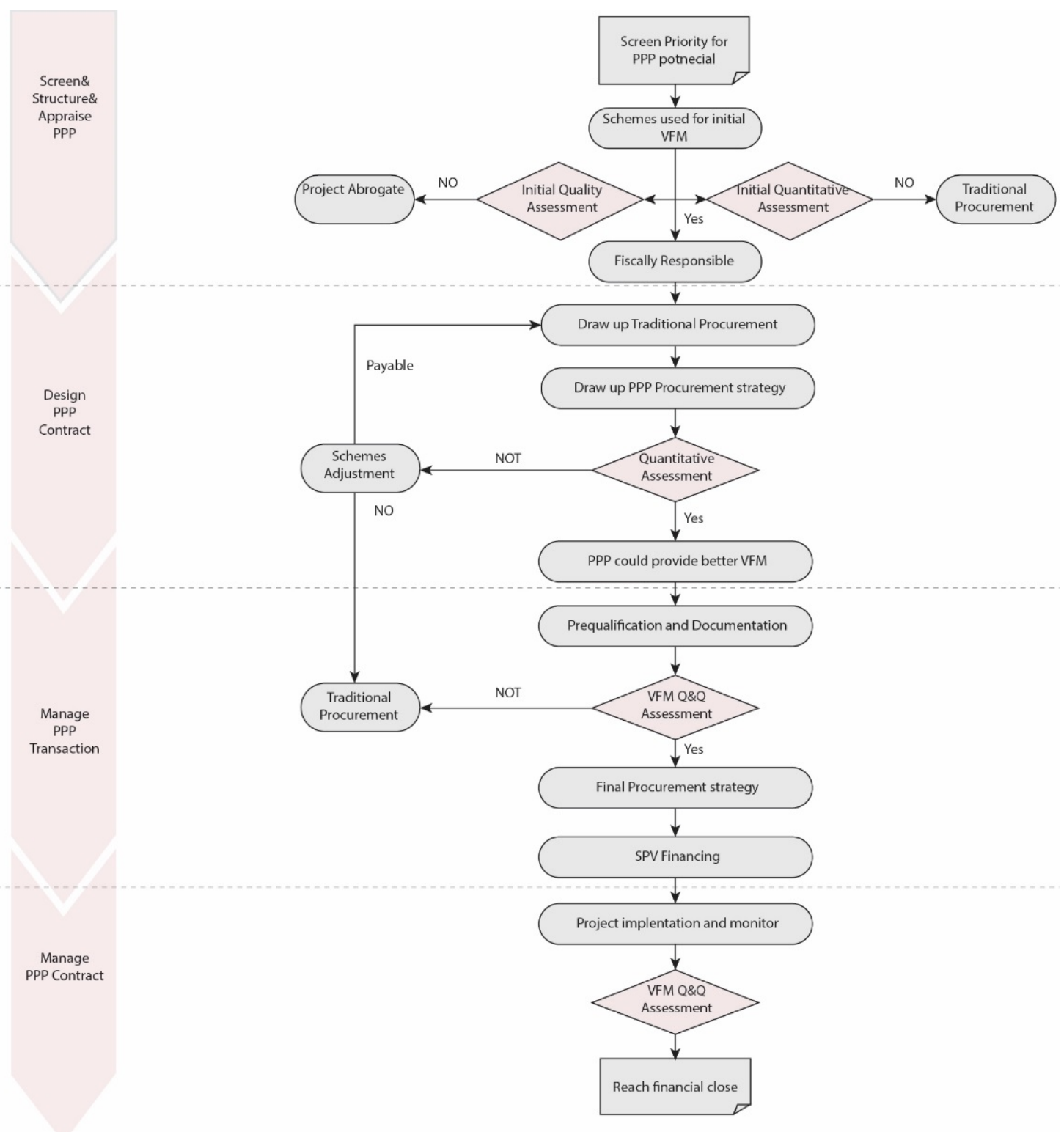

Figure 4. The VfM process through the project lifecycle.

\subsubsection{VfM Qualitative Assessment}

The qualitative assessment seeks to establish whether the relative performance could optimise the non-financial benefits of a project and enhance management efficiency. This contrasts with the early stages of traditional procurement processes [27]. Examples of indicators used in VfM qualitative assessment toolkits published by financial institutions from both the UK and China are summarised in Table 4 . 
Table 4. VfM qualitative assessment indicators in China and the UK. Source: values for money assessment guidance $[24,25]$.

\begin{tabular}{|c|c|}
\hline Indicators & Description \\
\hline Whole project lifecycle integration & $\begin{array}{l}\text { The extent of the contract that contains design-build, } \\
\text { financing, and operation demands. }\end{array}$ \\
\hline Performance outputs & $\begin{array}{l}\text { Whether clear requirements and benchmarking are } \\
\text { provided during the project monitor process. }\end{array}$ \\
\hline Soft Services & $\begin{array}{l}\text { Facilities management related to the day-to-day } \\
\text { supporting services required in the operation of } \\
\text { assets. }\end{array}$ \\
\hline Potential competition & $\begin{array}{l}\text { The competitive strength between social capitals and } \\
\text { whether to apply a proper measurement to promote. }\end{array}$ \\
\hline The political and legal environment & $\begin{array}{l}\text { Current policy and regulations that limit PPP } \\
\text { applications. }\end{array}$ \\
\hline Operational flexibility & $\begin{array}{l}\text { Various dimensions, including product flexibility, } \\
\text { volume flexibility, and delayed differentiation. }\end{array}$ \\
\hline Equity, efficiency, and accountability & $\begin{array}{l}\text { The viability of project finance equity, efficiency, } \\
\text { and accountability. }\end{array}$ \\
\hline Risk management & $\begin{array}{l}\text { The extent of risk identification and allocation that } \\
\text { progressed in the initial project stage. }\end{array}$ \\
\hline Innovation & $\begin{array}{l}\text { Whether the project outputs provide social } \\
\text { opportunities and benefits. }\end{array}$ \\
\hline Contract and assets Duration & $\begin{array}{l}\text { The expected period of service that the assets could } \\
\text { provide in the project lifecycle. }\end{array}$ \\
\hline Asset classification & The amount of project asset class in the PPP project. \\
\hline Project scale & $\begin{array}{l}\text { The amount of investment and asset value that fit in } \\
\text { the PPP applications. }\end{array}$ \\
\hline Incentives and Monitoring & $\begin{array}{l}\text { The process measures the service based on the agreed } \\
\text { standard. }\end{array}$ \\
\hline The whole Lifecycle costs & $\begin{array}{l}\text { The strategy, accuracy, and requirements of the } \\
\text { integrated lifecycle cost. }\end{array}$ \\
\hline Market Interest & $\begin{array}{l}\text { The sufficient market appetite for the projects; } \\
\text { evidence that indicates market failure and abuse. }\end{array}$ \\
\hline Finance feasibility & $\begin{array}{c}\text { The expectation of project attraction towards credit } \\
\text { and bond markets. }\end{array}$ \\
\hline Efficient Procurement & Procurement process that sustains the market interest. \\
\hline Authority Resources & $\begin{array}{c}\text { The public ideology of PPP, and the evaluation based } \\
\text { on authority abilities. }\end{array}$ \\
\hline
\end{tabular}

In the UK in 2006, the HM Treasury published a comprehensive guide to VfM assessment, written in light of substantial private financial initiative (PFI) experiences. This put forward a VfM structure and related factors [28]. The UK qualitative assessment was to be applied as a continuous investigation enacted in three stages: "program level", "project level", and "procurement level". At each stage of the assessment, specific questions from stakeholders must be answered. The indicators thereby functioned at each project stage to maintain the accuracy of information. Relevant questioning ensured appropriate and updated information. The resulting "viability", "desirability", and "achievability" were used to classify each of the indicators involved.

Notably, there is currently no well-accepted rating or weighting system applicable to all quality aspects, which leaves industry and project managers with a significant degree of freedom [29]. The notice published by the Ministry of Finance of the People's Republic of China initially introduced 
general requirements of quality measurement targets in VfM processes. Expert groups working on behalf of the Ministry of Finance took responsibility for the scoring assessments based on professional judgment (Figure 5). The VfM report template contained six primary evaluation indices, which accounted for $80 \%$ of the outcome. The remaining $20 \%$ involved at least six supplementary indices that covered significant elements beyond the basics [24]. As frequently seen in the literature, a five-point Likert scale method was used to identify the degree of performance of each index. The rating scale may contain various combinations of indices, according to individual project requirements.

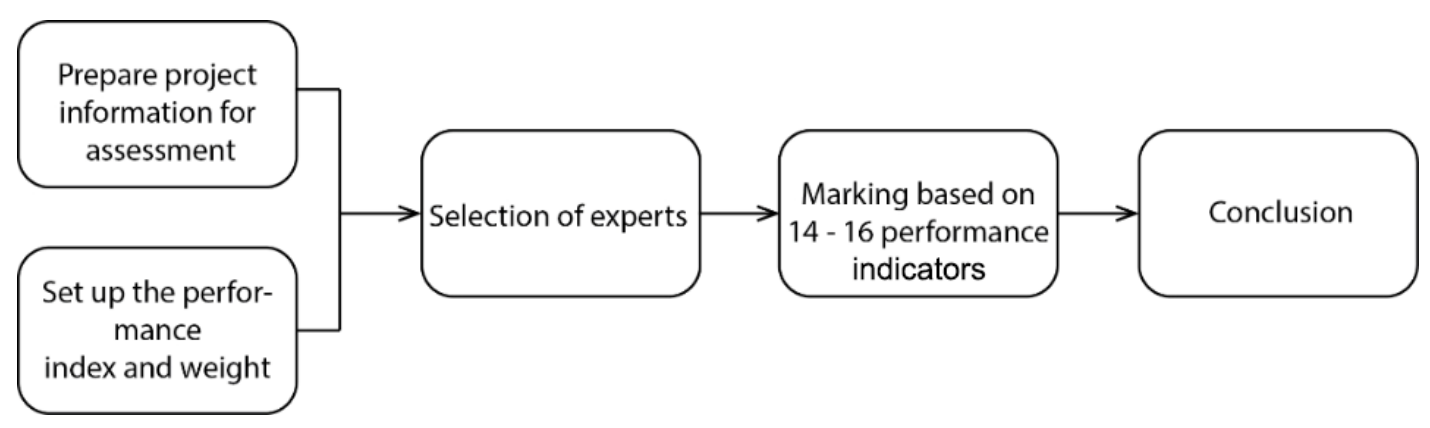

Figure 5. The qualitative assessment workflow in China [30].

However, while the template used in qualitative assessments provided more detailed rating methods, it still lacked supporting data and any information query system that would enrich evaluations. The assessment could be supported by the project information, including historical documentation. Project management should pay serious attention to nonfinancial factors, such as social and environmental impacts of the project [31] or contract management [32]. This is now regarded as an experience-based approach to estimating the level of project competitiveness. The current index for making a qualitative assessment is broad and requires a detailed subdivision. In addition, the benchmark of qualitative evaluation has not yet been comprehensively defined. Generally, "yes or no" scoring criteria are used in most cases, without reference to the multiple objectives related to project implementation. The detailed explanation of the assessment index indicates that the related contents should be checked in different stages. For example, general information such as "incentives and monitoring" can be tracked in project briefing documentation. Although the documentation in large-scale transportation projects uses typically a cloud-based platform, the position and digital label of the documentation are not connected to the assessment index. Documentation management is currently not using a standardised approach and is hardly connect with engineering database.

\subsubsection{VfM Quantitative Assessment}

As the vital assessment used to reflect the economic benefits of a project, the quantitative measurement may be a central issue when processing the VfM. Unlike qualitative appraisal, quantitative assessment in VfM requires the more direct computation of the PPP or PFI project's costs against a public-sector comparator (PSC). The PSC is based on a fictional model or an existing reference project, created using traditional models of public sector procurement. A PSC analysis is conducted from the programming level until financial close [33]. The calculated cost value, if using PPP as the procurement model, must always be less than costs likely to be incurred in a traditional public procurement model (shown in Figure 6). This must be achieved to a specified degree so that the special purpose vehicle (SPV) can be assured of sufficient motivation to action the business outlined. In addition, the calculated value should be continually updated as a clear picture of the risks that emerge over time [34]. 


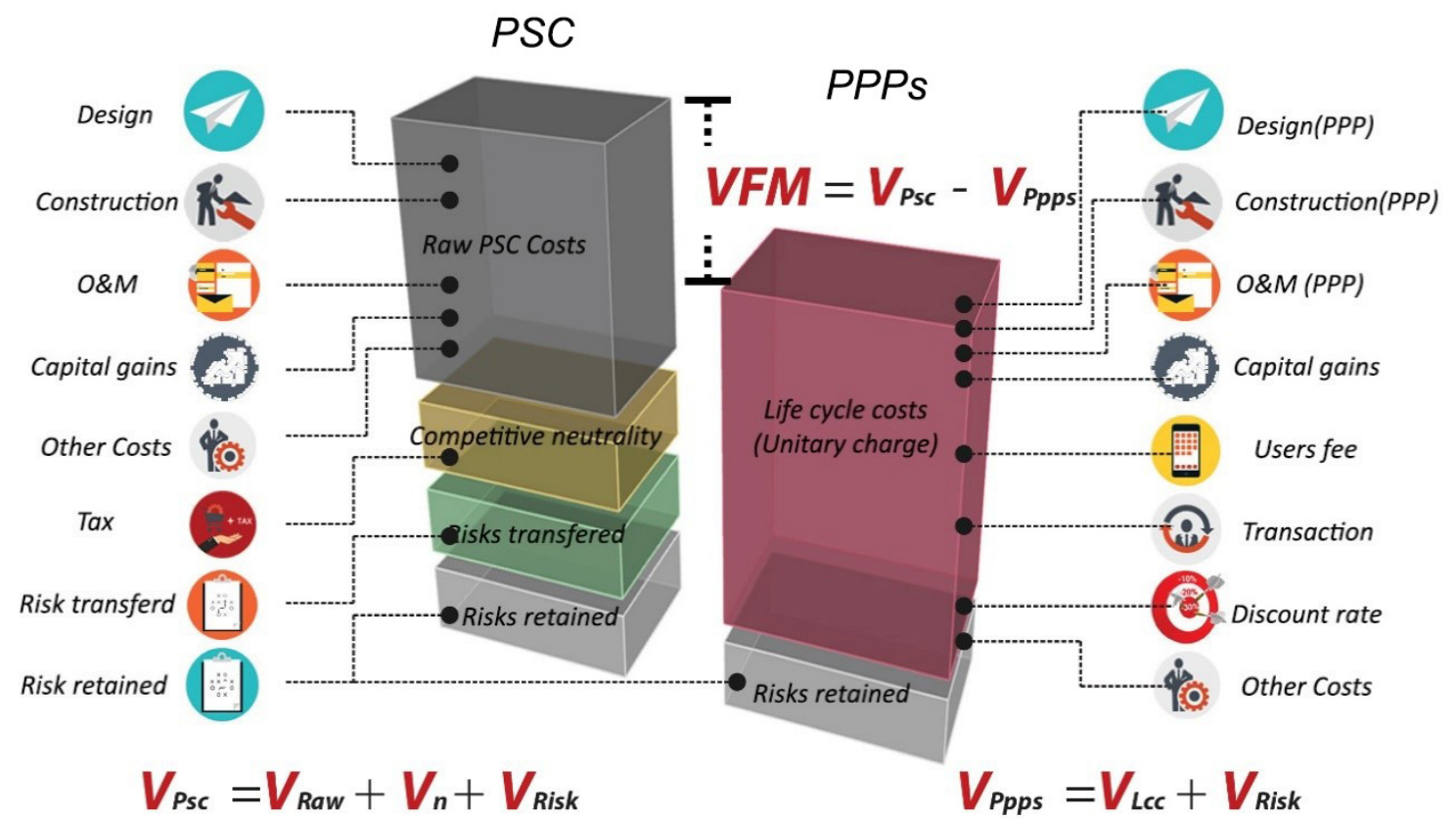

Figure 6. Structure for the quantitative assessment in the VfM process. PSC: public-sector comparator and LCC: lifecycle costs.

The calculations of the VfM from the quantitative assessment were closely related to the net present value (NPV) of the entire project lifecycle. The current model in the UK used the indicative present value for both PPP options and PSC value, with a traditional model providing public service assessments. Specifically, the PSC represents comprehensive scenario-setting that should achieve a level sufficient to reflect the procurement strategy. Many countries accept it. The UK government took the lead in standardising PSC content as a decision process to define where, when, and how to use privately financed infrastructure solutions [35]. According to the UK National Audit Office, a method of computing both PSC and PPP is continually updated. The critical component of the indicative present value in PSC focuses mainly on the cost of resources, transaction costs, and adjustment on tax and optimism bias. With the development of PSC accounting, the constitution of PSC now can be divided into four parts: the raw PSC value, the value of risk transfer, retention value, and competitive tax adjustment [36].

In the quantitative assessment content, the raw PSC value is related to the resource-based costs, as shown in Figure 6. The cost of project design, construction, operating, and maintenance must be added to consulting service fees related to the project. The capital income as the property transfer fees or user fees should be deducted. To eliminate the advantages of public ownership, the value of competitive neutrality adjustment is used to modify the tax and responsibility cost to the public sector to achieve equality of competition [37]. It is worth mentioning that adaptive risk allocation and management indirectly affect the PSC value in the PSC calculations, which requires a reference project to be set up. This project is assumed to use the traditional procurement approach rather than the PPP model. The main advantage of the PPP/PFI model is that a considerable degree of risk may be transferred to the private sector. Therefore, these costs should be added in the traditional scenario in the PSC calculations. The value of transferable risk is converted to a net present value using its occurrence probability in most of the cases, as shown in Table 5. 
Table 5. Example of risk-related cost using the probabilistic method.

\begin{tabular}{llll}
\hline Risk Event & Risk Consequences & Risk Probability & Cost \\
\hline Risk Event 1 & Cost-saving 5\% & 0.7 & \\
Risk Event 2 & Cost overrun 5\% & 0.8 & Cost overrun $5 \%$ \\
Risk Event 3 & Cost overrun $10 \%$ & 0.3 & \\
Risk Event 4 & Cost overrun $15 \%$ & 0.1 & \\
\hline
\end{tabular}

The PSC-based appraisal procedure is now regarded as the most effective benchmark for measuring the quantitative aspects of the VfM. However, its value has been disputed [38]. The current calculations are not holistic, and the extent of its synchronisation with the project lifecycle is still under development. There is no doubt that such a VfM quantitative assessment is supposed to remain its objective along the project lifecycle and has clear steps and procedures. It is anticipated that different computing methods are used at various project stages. When it comes to the quantitative assessment, the process for sharing information about the assets, the information required for the PSC or PPP value should be attached to the VfM system.

To summarise, VfM assessment issues include:

- Qualitative assessment lacks an appropriate information query system, i.e., one able to support information queries and the position.

- The project data currently used for quantitative financial accounting are historical and may generate unreliable results. The information that could be acquired from multiple sources and resources is neither sourced nor represented, which brings about issues with the information exchange necessary for calculating the present values.

Parties to PPP projects face multiple barriers because the provision of accurate VfM assessment cannot be guaranteed. A substantial proportion of $\mathrm{VfM}$ indicators are challenging to measure using standard means, yet this situation could be improved through technological innovation. The prevalence of PPPs in infrastructure projects also creates significant issues at various stages. From a project management point of view, well-organised data management at the initial stage is required. The following section suggests that the application of BIM could more effectively and fully express the VfM. It is worth mentioning that the VfM assessment in the later ex-post-project stage is hardly implemented in most of the PPP cases, and quite a few literature studies stress these issues. This is perhaps that VfM in the early stage (screen PPP) cannot utilise the well-constructed information and database to capture the key information in real-time smartly. The lack of standardised information exchange and well-organised document structure makes it difficult to continuously perform the assessment along the project lifecycle.

\section{A Statistical Review of BIM Development}

\subsection{The Literature Review of BIM and VfM}

According to Eastman [39], the benefits of BIM should influence a project's preconstruction phase, driven by the owner. The phases of design, construction, and fabrication, which are primarily driven by contractors, as well as the post-construction period, driven by operators, will also be affected. The use of BIM as the foundation for building engineering projects dates back to the early 1990s [40]. The term "building information management" is now used to describe a process whereby the digital approach guides the project construction and operation. This approach and, more precisely, the enhanced information-sharing properties within it, could be beneficial to the public sector and political behaviour. BIM technologies serve to build a low-cost integrated information management system in construction projects [41]. The finalised BIM model has tremendous potential, not only to help contractors for inspection purposes but, also, to aid in intelligent management at a municipal level [42]. 
BIM-related research has gradually covered both quantitative and qualitative aspects of projects. To stress this possibility, a BIM-based literature review is presented in this section. Ninety-seven research articles related to BIM cost functions and 118 research articles related to project quality management over the last ten years were collected and analysed. A set of keywords was identified for classification using Science Direct and Scopus. The main keywords were "BIM", "building information management", "cost", "procurement", "documentation", "contract", "risk", and "quality".

As shown in Table 6, for the qualitative aspect, many research papers are presenting how BIM help to improve the project quality or building performance. The literature volume also consisted of papers that concern the BIM functions on project internal quality controls. The results also revealed that the prevailing BIM in construction is spreading out to the procurement level. Based on this, there is research that comes down to BIM-based documentation and contract management. Abdirad [43] stated that the BIM contracting provision could be stressed in the future to add more industry requirements to the existing contracts. However, there are few numbers of research that focus on quality information management on the procurement level. Ramanayaka and Venkatachalam [44] pointed out in the research that the BIM stimuli set by developers do not have close attention towards integrating the qualitative features and project externalities. This is likely due to the information used in BIM that mainly focuses on the object level, and the data standard is not ready to cover the project management field.

Table 6. The distribution of building information management (BIM) research articles on both the qualitative and quantitative aspects.

\begin{tabular}{ll}
\hline BIM-Related Research Articles on the Qualitative Aspects & Number \\
\hline Documentation management & 4 \\
Quality control in facility management & 13 \\
Quality performance improvement & 35 \\
Contract and process management & 5 \\
Quality control in construction & 24 \\
Quality control in procurement strategy & 7 \\
Risk management & 30 \\
\hline BIM-Related Research Articles on the Cost-Based Quantitative Aspects \\
\hline Data analysis for cost estimation & 11 \\
Integration with the design stage for cost efficiency & 14 \\
The relation between cost and other performance & 16 \\
The cost management scheme & 17 \\
Cost for lifecycle assessment & 15 \\
Construction cost estimation & 24 \\
\hline
\end{tabular}

In the field of cost management, except the cost estimation and 3D technology, some papers are focusing on applying BIM for construction cost estimating [45-47], construction quantity take-off schemes [48-50], and project scheduling [51-53]. A few pieces of research stress the integration using BIM to facilitate cost-based construction management and lifecycle assessment. There also exist several studies that propose to combine the BIM-based cost function and other domain knowledge for the improvement of the project management efficiency. As for the deliverable data level, Zhiliang [54] suggested to use the industry foundation class (IFC) standard and establish the IFC-based information model for project tendering in China, while Kehily [55] used BIM that incorporated with whole lifecycle costs (WLCC) data to progress the calculations.

Information management using BIM can connect quantitative and qualitative fields within the VfM assessment but lacks a specific scheme to influence the PPP project justification. 


\subsection{BIM and VfM}

From an engineering performance perspective, the benefits of BIM are the provision of an environment, which refers to the management framework, standards, assessment methods, and tools, through the whole project lifecycle (as shown in Figure 7). PPP, however, is extensively concerned with more holistic and sustainable business targets. This paper suggests that PPP could be an ideal platform for BIM, as it facilitates whole lifecycle measurements and information editing and sharing with digital plans. The lack of supporting data and incomplete framework in current VfM assessments demands a holistic information system that contains lifecycle functionalities that can respond to change. The reason that BIM can be helpful on this matter is based on its standardised data format to represent the project objects and other elements, such as document and cost attributes. Besides, the structured information exchange and flow in the BIM-based project can also contribute to the VfM assessment by setting up an advanced assessment so that the experts can obtain the required information automatically. Most importantly, the BIM-based assessment approach can connect with different project knowledge bases such as ontology to facilitate project decision-making by providing solid, real-time data.

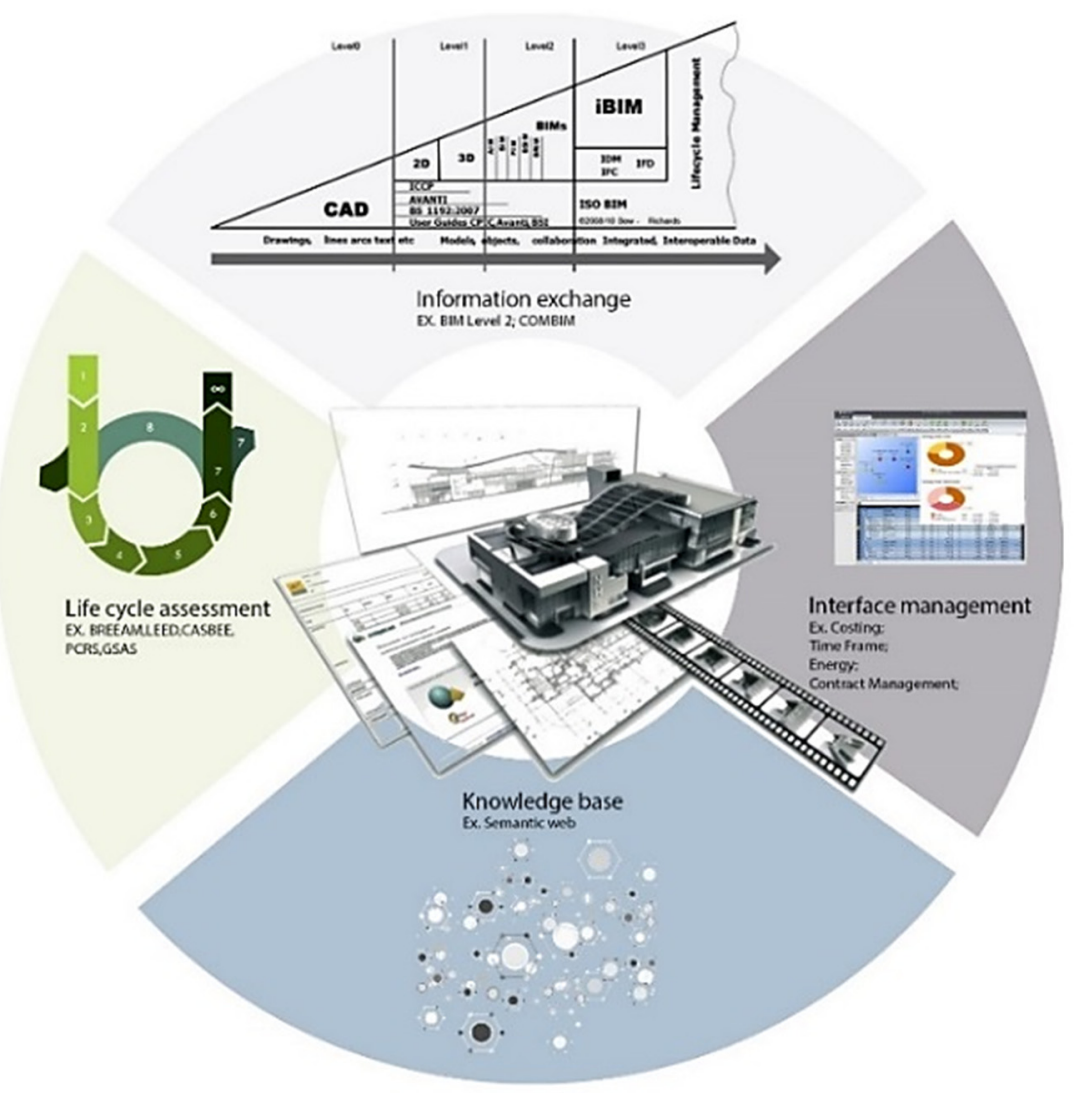

Figure 7. The concept of building information management (BIM).

The important indicators that align with the contract agreement in the VfM process are frequently subject to regulations and requirements to periodically monitor the project performance. In most PPPs, the key project targets are written into the VfM qualitative assessment, which has a close relation with the performance measurement in the later stage, while some of the indicators may be taken into consideration for lifecycle evaluation. The actions and outcomes of public service functions in major infrastructure projects should be strictly supervised by the government, which assesses the project operation status, including its adaptability and impact in social and environmental terms [56]. Table 7 provides the VfM indicators with the corresponding available BIM functions and associated tools and carriers based on the World Bank's recommendations. The use of BIM within it is supported. 
Table 7. VfM indicators and corresponding BIM function resources could potentially maximise the benefits along the entire project lifecycle. PEP: project execution plan, dPOW: a digital plan of work, and PSC: public-sector comparator.

\begin{tabular}{|c|c|c|c|}
\hline Stages & VfM Assessment Contents & BIM Functions & Tools/Carriers \\
\hline Screen & VfM methodology & Information formatting & $\begin{array}{l}\text { dPOW; } \\
\text { OIR(Organization } \\
\text { information } \\
\text { requirement) }\end{array}$ \\
\hline \multirow[t]{2}{*}{ Structure and Appraise } & $\begin{array}{l}\text { VfM qualitative } \\
\text { assessment } \\
\text { (Whole project lifecycle } \\
\text { integration; Operation } \\
\text { flexibility } \\
\text { Risk management; Contract } \\
\text { and assets Duration; } \\
\text { Incentives and Monitoring; } \\
\text { Market interest; Efficient } \\
\text { procurement) }\end{array}$ & $\begin{array}{l}\text { Compliance checking; } \\
\text { Semantic BIM approach; } \\
\text { Documentation Query; } \\
\text { Information exchange; } \\
\text { Model simulation; }\end{array}$ & $\begin{array}{l}\text { Projectwise } \\
\text { InfraWorks } 360 \\
\text { BIM } 360^{\mathrm{TM}} ; \\
\text { Viewpoint } \\
\text { The semantic approach } \\
\text { aligns with BIM }\end{array}$ \\
\hline & $\begin{array}{l}\text { VfM Quantitative } \\
\text { assessment (PSC) } \\
\text { Facility management costs, } \\
\text { Construction costs, } \\
\text { Operation costs, } \\
\text { Transportation costs, Human } \\
\text { resource costs, Risk-related } \\
\text { costs, and Other costs }\end{array}$ & $\begin{array}{l}\text { Cost analysis; } \\
\text { Quantities take-off }\end{array}$ & $\begin{array}{l}\text { Five Dimension BIM } \\
\text { tools; } \\
\text { PEP } \\
\text { Solibri; CostX®; } \\
\text { The semantic approach } \\
\text { aligns with BIM }\end{array}$ \\
\hline
\end{tabular}

Regarding the VfM in the initial screen stage of a PPP project. The investment planning and unsolicited proposals and initial outputs of the project in this phase could benefit from a digital plan of work (dPOW) that uses plain language questions (PLQs) to capture clients' needs and generate information exchange requirements in the initial stage [57]. In this phase, the information is transmitted to an initial asset management inquiry that covers clients' needs. The client-based organisation like SPV could take on updating further asset and employee information, which is used in project monitoring and assessment. Furthermore, the VfM assessment can construct a library of supporting information for reference in the PSC project. Although currently, the information available in the earlier stage of a project is not productive enough to generate a convincing VfM output, with BIM support for integration, it would be possible to create favourable premises for further information delivery.

The structuring and appraisal phases of PPP involve the vital process and information that determines the fundamentals of the project, including risk identification and allocation, feasibility, and viability study, which could be added to the project execution plan (PEP). Risk-related management requirements are directly connected with the VfM assessment and could be represented explicitly by using domain-related indicators to define the risk contents. A semantic BIM approach can be used at this stage. The integration of ontological knowledge and industry foundation class (IFC) data provides a list used by this model specifically for risk events in PPP. The relevant information could be made into a semantic environment and displayed through domain-based taxonomy. Since this stage occurs close to the procurement, rich data should provide the required scope to commence VfM. The information exchange from the BIM environment could support parties to source relevant data for the employers' information requirement (EIR) and provide the initial design or existing models for NPV. A 5D representation, which includes the digital design, should have sufficiently detailed asset information. The current cost-related tools align with BIM and, thus, could provide favourable measurements to make it possible to structure value more holistically. At this point, the quantitative assessment will not rely on historical data, because BIM provides a real-time information flow [8]. 


\subsection{Semantic BIM-Based Assessment}

The previous review chapter discussed BIM-related research and indicated the possibility that the information and process in a BIM system could be applied to the PPP knowledge domain. The IFC-based data structures and related information exchange standards have the potential to provide support to both the qualitative and quantitative aspects of VfM. However, there is a need for the knowledge development of VfM in PPP projects, which requires a method of sharing, exchanging, and reusing domain knowledge. This paper discusses how a semantic BIM could facilitate the integration of information in PPP due to its focus on the project scale, type, and domain-related knowledge. In addition, it would help to manage the risks using clear taxonomy and could eventually provide better deliverables for VfM purposes.

The semantic web represents explicit domain knowledge that could be related to the built environment. That information is initialised by human knowledge-oriented language and linked to multiple domain knowledge bases [58]. As an integral component of the semantic web, ontology plays a significant role, since it structures the implementation framework that could be made readable by computer language applications. Ontology web language (OWL), the language of expression, has been given rule-based functions to query information from a different knowledge base and then provide the path for data management [59]. An ontological representation allows sophisticated knowledge to be incorporated into a project system that is implemented logically [60]. Unlike general object-oriented programming models in software development that enable the model's transformation into software artefacts, a model in an ontological environment contains semantic relationships, domain knowledge annotation, and rich rules for information management [61].

The semantic approach, interacting with BIM technology, has, in recent years, led to a significant shift in research and development in the architecture, engineering, and construction (AEC) industries (Figure 8). Semantic web technologies added value to BIM by permitting data integration and complex search queries across several data sources [62]. Concerned with domain use, recent outlook and review articles have considered the latest semantic methods. Research by Mignard and Nicolle [63] proposes the ontology applications by merging BIM and geographic information system (GIS) data for urban scale facility management. Wetzel and Thabet [64] proposed a BIM-based ontology framework to support safe maintenance and repair practices for the construction facility management phase. Hou [65] created OntoSCS, an ontology for sustainable concrete structures, using semantic web rule language (SWRL) to optimise the structural design solutions. Zhang et al. [66] developed an ontology-based job hazard analysis for construction safety management, while Tomašević et al. [67] applied a facility ontology to energy management. In the field of cost-related ontology, Cheung et al. [68] proposed schematic BIM models using a low-impact design explorer, which was a knowledge-based tool to define and estimate the early stage costs. Lee et al. [69] proposed an ontological inference process for building costs; this translated the IFC XML (Extensible Markup Language), extracted from the BIM to a resource description framework (RDF) format that contained the information required for semantic reasoning. The process takes into consideration the working conditions and work items to help estimators decide on an efficiently automated method. Abanda [47] developed new rules of measurement ontology for cost estimations during the tendering stage. In the field of construction risk management, Tserng et al. [70] developed an ontology-based framework of risk management that addressed risk identification and analysis concerning the project flow of design and construction. Ding et al. [71] constructed a comprehensive ontological prototype to manage the construction risk. The data drawn from the BIM could be extracted or mapped to a risk knowledge base-a semantic environment providing reasoning and retrieval to corresponding objects. These studies were all performed within a single field; however, all failed to contribute to a structural procurement and had limited potential for use in a PPP model. 


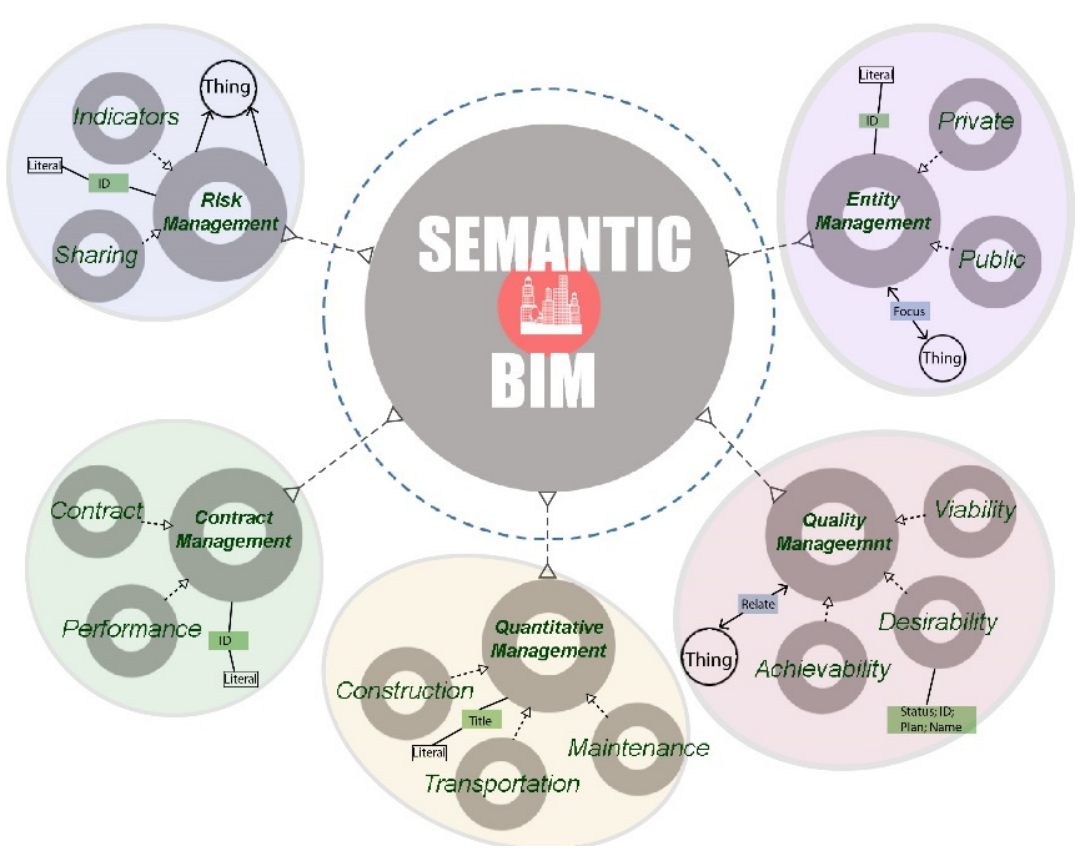

Figure 8. BIM aligned with the semantic function.

\section{Discussion-Research Gaps Identified}

BIM research has demonstrated its potential of application in VfM. These benefits include better collaboration between different stakeholders, as well as advanced analytics and the optimisation of information management. The lack of reliable information support in VfM can be improved by using the standardised data and information exchange process in BIM. The existing BIM tools with various functions can also help VfM to construct a better decision-making environment. Nevertheless, a few research gaps were identified by this review, as below:

- Information exchange-A scheme that highly accepted information delivery was lacking. Although there are various implementation approaches for calculating costs and quality features using an IFC model in the construction stages, no information exchange scheme was fully extended to encompass the significant elements of VfM within PPP infrastructure projects, especially in operation and maintenance stage. This is most likely due to the complexity of PPP, involving various types of infrastructure works. In addition, the growing use of big data approaches and machine-learning techniques are reducing the need for structured data formats. These emerging methods still require integrated datasets and explicit exchange requirements to capture the asset information in the very beginning and, later on, benefits the operation and maintenance [72-75]. Therefore, determining a universally agreed upon information exchange scheme is still a high-profile research area.

- Alignment of the VfM knowledge with the supporting information-There were numerous studies that used the BIM information and ontologies to automate various support solutions. These knowledge-based approaches have been applied to the PPP business domain at the organisation level, where BIM could benefit the project justification and procurement plans is an area yet to be explored and would be relevant to the various types of construction-based projects. VfM in PPP requires comprehensive qualitative and quantitative assessments. Due to the different types of procurements, VfM also requires knowledge support to facilitate a much more holistic process that considers determinants, especially the results of quantitative PSC and PPP values. These processes could be rendered much more effective.

- Data integration environment-BIM-based management systems have focused mainly on technical applications for integrating additional dimensions into the already developed 3D information model. The ability to analyse and visualise the data has only been determined within construction 
projects. However, even the IFC structure is expanding. The current datatype is difficult to use for project external data, such as financial and organisational data. The approach of placing all the project external data and internal data into a single database is urgently required, as this approach could be applied to real-world projects to provide more accurate results and create benefits in operation and maintenance. In such cases, the data extracted from BIM can guarantee the real-time accuracy of the internal project measurements. In addition, the linear or nonlinear data analysis approach could measure external performance. Therefore, a virtualised data integration engine should be explored to provide both one location for information and a database that contains project externalities.

\section{Roadmap for BIM-based VfM in PPP}

From the identified gaps, a corresponding roadmap for "BIM-based VfM" is proposed to direct future research. Three critical steps in the VfM process in response to the three primary research gaps are: (1) the information exchange scheme development for VfM, (2) VfM knowledge base, and (3) database that includes project externalities.

Since 2009, the UK government has based its approach on the concept of "BIM levels" [76]. This highlights integrated data sharing and exchange capabilities in a way that combines all of the geographical, administrative, and object information. The BSI group has worked with the industry to present a national guide to BIM level 2 applications. This comprehensively covers client and contractor interests and has been applied to massive projects, such as the Crossrail and High Speed 2 projects, confirming its place among the UK's leading digital technologies for infrastructure [77]. Regarding the technological development of BIM, strategies were proposed that encompassed cross-sector collaboration and focused on more efficient procurement, delivery, and operations to meet the lifecycle's fiscal and sustainability objectives [78]. Its development trace has shown that BIM has the potential to work with the PPP model by challenging the current forms of electronic procurement [79].

The BIM structure could contribute a great deal to the roadmap. BIM not only provides a digital platform but, more importantly, it provides a common data exchange platform that could be used throughout a PPP project's lifecycle. BIM-based VfM could also play a greater role at an earlier stage. The information extracted from the business outline could be stored in a common data environment; for example, BIM could help to fulfil the requirement from a client's point of view. Even if the information is not rich enough to entirely process the VfM, a referenced project should be set up at this stage to gather all the relevant information for initialising the PSC value. The acquisition of raw PSC data is achieved through a strict cost-effectiveness analysis to touch design, construction, and maintenance, which provides a basic data profile for quantitative assessment throughout the project and facility management.

Along with the exchange scheme, information from the BIM is added to the project's shared data environment and delivered to the ontological framework. The ontology should directly link IFC/XML from the BIM to the key performance indicators of the VfM. Ontology can connect to other knowledge domain sources to align with information in financial and economic affairs. The ontological structure is also built to maximise the project quality performance and provide information query abilities to qualitative assessments. With the procurement strategy continually updated, the semantic framework will contribute to the assessment. For more comprehensive WLCC computing features, such as the cost of risk transferred, other external performances could be simulated based on the historical data. The decision will be based on the VfM outputs. Once targets in both quality and quantity aspects are fulfilled, the project flows to the next step. The value is decided by the final procurement strategy and will continually function with project supervision.

The advantages of BIM aligned with a semantic approach in PPP could benefit the procurement decision as follows: 
- The semantic environment has the potential to connect to the project information from a shared data environment. Information query and qualitative assessment could be facilitated by building up knowledge bases for different types of PPP projects.

- The information extracted from the BIM, which is a vital element of information initialisation, provides high-quality data input to guarantee the accuracy and high levels of synchronisation for the quantitative assessment. The PPP lifecycle project flow is considered, and the BIM enhances the information exchange.

\section{Conclusions}

The assessment of VfM seeks to capture the possible profits throughout the program, project, and procurement levels. Even the current VfM is limited to the available information. It is possible to structure the VfM initially with a structured knowledge base and information support. This paper presents a comprehensive review of the methods used in the VfM contents and related information support. The fundamentals of the VfM are still under development, and a more holistic workflow is required to optimise both the qualitative and quantitative assessment processes. The literature related to the PPP infrastructure was insufficient in terms of the structure of the VfM. The procedures applied in the VfM toolkits still used traditional measures, which are limited regarding both automation and the accuracy of decision-making. Thus, it is necessary to build a VfM strategy that can provide more valuable deliverables.

Currently, the application of BIM techniques to PPP projects is still limited and has had minimal impact on the lifecycle information management. BIM technology is expanding into different types of infrastructure engineering projects. However, the current practices only stress functionality on the project level and rarely addresses the programme and procurement levels. The BIM run by construction industries, design institutions, consulting firms, and research institutions can implement the BIM from a certain perspective. However, these implementations fail to stress the lifecycle aspects, especially from the initial appraisal stage. By matching the BIM function to the essential elements of the VfM, as well as the review of knowledge-oriented BIM approaches, the VfM assurance process could be supported by both qualitative and quantitative assessments. The application of elements of BIM to VfM processes could also be used to identify and organise the relationships between and attributes of risk factors and events, thereby producing more holistic VfM results.

Through a literature review concerning both VfM assessments and BIM, this paper has identified the scope for a partnership between these two concepts. As a lifecycle project management strategy, PPP focuses mainly on procurement benefits, but to achieve these, the PPP approach requires a lifecycle information exchange and management platform, where BIM can play a significant role. The VfM process could, throughout the entire PPP workflow, determine whether the provided value is sufficient. The data would be attained as a result of using the PPP procurement model, rather than a traditional approach. The current BIM approach implemented within the engineering project areas of measurement and evaluation has not yet been able to connect to the VfM. To explore whether the BIM has the comprehensive ability to facilitate the VfM assessment, this paper addressed these gaps present in the current knowledge. A BIM-based decision-making roadmap in the VfM was proposed. Future works should cover the comprehensive semantic development of this knowledge base, along with an automatic information exchange scheme.

Author Contributions: Conceptualization, G.R. and H.L.; Methodology, G.R. and J.Z.; Analysis, G.R.; Investigation, G.R.; Resources, G.R. and J.Z.; Writing-Original Draft Preparation, G.R.; Writing-Review \& Editing, G.R.; Supervision, H.L. All authors have read and agreed to the published version of the manuscript.

Funding: This research received no external funding.

Acknowledgments: The authors would like to acknowledge the support provided by Cardiff University, UK, Educational Department of Liaoning Province, China and Department of Science \& Technology of Liaoning Province.

Conflicts of Interest: The authors declare no conflict of interest. 


\section{References}

1. Zhang, S.; Chan, A.P.C.; Feng, Y.; Duan, H.; Ke, Y. Critical review on PPP Research-A search from the Chinese and International Journals. Int. J. Proj. Manag. 2016, 34, 597-612. [CrossRef]

2. Du, L.; Tang, W.; Liu, C.; Wang, S.; Wang, T.; Shen, W.; Huang, M.; Zhou, Y. Enhancing engineer-procure-construct project performance by partnering in international markets: Perspective from Chinese construction companies. Int. J. Proj. Manag. 2016, 34, 30-43. [CrossRef]

3. Farquharson, E.; Encinas, J.; Yescombe, E.R.; Torres de Mästle, C. How to Engage with the Private Sector in Public-Private Partnerships in Emerging Markets; World Bank Publications: Bretton Woods, NH, USA, 2011; ISBN 9780821378632.

4. Shaoul, J. Financial Black Holes: Accounting for Privately Financed Roads in the UK.; The Institute of Chartered Accountants of Scotland: Edinburgh, UK, 2011; Volume 20, ISBN 9781904574286.

5. European PPP Expertise Centre (EPEC). PPP Motivations and Challenges for the Public Sector Why (not) and How. 2015, p. 35. Available online: https://www.eib.org/attachments/epec/epec_ppp_motivations_and_ challenges_en.pdf?f=search\&media=search (accessed on 16 September 2020).

6. Hall, D. Why Public-Private Partnerships Don't Work the Many Advantages of the Public Alternative. 2014. Available online: http://www.world-psi.org/sites/default/files/documents/research/rapport_eng_56pages_ a4_lr_0.pdf (accessed on 16 September 2020).

7. ACCA. Taking Stock of PPP and PFI around the World; Certified Accountants Educational Trust for the Association of Chartered Certified Accountants: London, UK, 2012; ISBN 9781859084755.

8. Love, P.E.D.; Liu, J.; Matthews, J.; Sing, C.P.; Smith, J. Future proofing PPPs: Life-cycle performance measurement and Building Information Modelling. Autom. Constr. 2015, 56, 26-35. [CrossRef]

9. Ren, G. Knowledge Management in PPP Decision Making Concerning Value for Money; Cardiff University: Cardiff, UK, 2019.

10. Henjewele, C.; Sun, M.; Fewings, P. Critical parameters influencing value for money variations in PFI projects in the healthcare and transport sectors. Constr. Manag. Econ. 2011, 29, 825-839. [CrossRef]

11. World Bank. Public-Private Partnerships Reference Guide; World Bank Publications: Bretton Woods, NH, USA, 2014.

12. Chou, J.; Pramudawardhani, D. Cross-country comparisons of key drivers, critical success factors and risk allocation for public-private partnership projects. Int. J. Proj. Manag. 2015, 33, 1136-1150. [CrossRef]

13. Hwang, B.; Zhao, X.; Gay, M.J.S. Public private partnership projects in Singapore: Factors, critical risks and preferred risk allocation from the perspective of contractors. Int. J. Proj. Manag. 2013, 31, 424-433. [CrossRef]

14. Liu, T.; Wang, Y.; Wilkinson, S. Identifying critical factors affecting the effectiveness and efficiency of tendering processes in Public-Private Partnerships (PPPs): A comparative analysis of Australia and China. Int. J. Proj. Manag. 2016, 34, 701-716. [CrossRef]

15. Thomas Ng, S.; Tang, Z.; Palaneeswaran, E. Factors contributing to the success of equipment-intensive subcontractors in construction. Int. J. Proj. Manag. 2009, 27, 736-744. [CrossRef]

16. Tang, L.; Shen, Q. Factors affecting effectiveness and efficiency of analyzing stakeholders' needs at the briefing stage of public private partnership projects. Int. J. Proj. Manag. 2013, 31, 513-521. [CrossRef]

17. Toor, S.; Ogunlana, S.O. Critical COMs of success in large-scale construction projects: Evidence from Thailand construction industry. Int. J. Proj. Manag. 2008, 26, 420-430. [CrossRef]

18. Wibowo, A.; Mohamed, S. Risk criticality and allocation in privatised water supply projects in Indonesia. Int. J. Proj. Manag. 2010, 28, 504-513. [CrossRef]

19. Xu, Y.; Yeung, J.F.Y.; Chan, A.P.C.; Chan, D.W.M.; Wang, S.Q.; Ke, Y. Developing a risk assessment model for PPP projects in China-A fuzzy synthetic evaluation approach. Autom. Constr. 2010, 19, 929-943. [CrossRef]

20. Zhao, X.; Hwang, B.G.; Gao, Y. A fuzzy synthetic evaluation approach for risk assessment: A case of Singapore's green projects. J. Clean. Prod. 2016, 115, 203-213. [CrossRef]

21. Sobhiyah, M.H.; Bemanian, M.R.; Kashtiban, Y.K. Increasing VFM in PPP power station projects-Case study: Rudeshur gas turbine power station. Int. J. Proj. Manag. 2009, 27, 512-521. [CrossRef]

22. Office of Transportation Public Private Partnerships. PPTA Value for Money Guidance; Office of Transportation Public Private Partnerships: Richmond, VA, USA, 2011.

23. World Bank. Benchmarking Public-Private Partnerships Procurement 2017; World Bank: Bretton Woods, NH, USA, 2017. 
24. Ministry of Finance of China. PPP Value for Money Guidance; Ministry of Finance of China: Beijing, China, 2014.

25. HM Treasury. Value for Money Assessment Guidance; HM Treasury: London, UK, 2006.

26. Cowper, J.; Samuels, M. Performance benchmarking in the public sector: The United Kingdom experience. Benchmarking Eval. Strateg. Manag. Public Sect. 1997, 5, 11-32.

27. Morallos, D.; Amekudzi, A.; Ross, C.; Meyer, M. Value for Money Analysis in U.S. Transportation Public-Private Partnerships. Transp. Res. Rec. J. Transp. Res. Board 2009, 2115, 27-36. [CrossRef]

28. HM Treasury. PF2: A User Guide; HM Treasury: London, UK, 2012.

29. Treasury, H. Standardisation of PF2 Contracts; HM Treasury: London, UK, 2012.

30. Hongyue, W.; Jingfeng, Y.; Jing, D. Qualitative Evaluation of Value for Money of International PPP Project and Enlightenment to China. Constr. Econ. 2017, 38, 38-42. [CrossRef]

31. Mota, J.; Moreira, A.C. The importance of non-financial determinants on public-private partnerships in Europe. Int. J. Proj. Manag. 2015, 33, 1563-1575. [CrossRef]

32. Parker, D.; Hartley, K. Transaction costs, relational contracting and public private partnerships: A case study of UK defence. J. Purch. Supply Manag. 2003, 9, 97-108. [CrossRef]

33. Grimsey, D.; Lewis, M.K. Are Public Private Partnerships value for money?: Evaluating alternative approaches and comparing academic and practitioner views. Account. Forum 2005, 29, 345-378. [CrossRef]

34. Akintoye, A.; Hardcastle, C.; Beck, M.; Chinyio, E.; Asenova, D. Achieving best value in private finance initiative project procurement. Constr. Manag. Econ. 2003, 21, 461-470. [CrossRef]

35. Bain, R. Public sector comparators for UK PFI roads: Inside the black box. Transportation (Amst) 2010, 37, 447-471. [CrossRef]

36. National Audit Office. Review of the VFM Assessment Process for PFI; HM Treasury: London, UK, 2013.

37. Cruz, C.O.; Marques, R.C. Infrastructure Public-Private Partnerships: Decision, Management and Development; Springer International Publishing: Berlin, Germany, 2013; ISBN 9783642369100.

38. Bidne, D.; Kirby, A.; Luvela, L.J.; Shattuck, B.; Standley, S.; Welker, S. The Value for Money Analysis: A Guide for More Effective PSC and PPP Evaluation; National Council on Public-Private Partnerships: Washington, DC, USA, 2012.

39. Eastman, C.M.; Eastman, C.; Teicholz, P.; Sacks, R.; Liston, K. BIM Handbook: A Guide to Building Information Modeling for Owners, Managers, Designers, Engineers and Contractors; Wiley: Hoboken, NJ, USA, 2011; ISBN 9780470541371.

40. van Nederveen, G.A.; Tolman, F.P. Modelling multiple views on buildings. Autom. Constr. 1992, 1, $215-224$. [CrossRef]

41. Bradley, A.; Li, H.; Lark, R.; Dunn, S. BIM for infrastructure: An overall review and constructor perspective. Autom. Constr. 2016, 71, 139-152. [CrossRef]

42. Hartmann, T.; Van Meerveld, H.; Vossebeld, N.; Adriaanse, A. Aligning building information model tools and construction management methods. Autom. Constr. 2012, 22, 605-613. [CrossRef]

43. Abdirad, H. Advancing in Building Information Modeling (BIM) Contracting: Trends in the AEC/FM Industry. In Proceedings of the AEI 2015, Milwaukee, WI, USA, 24-27 March 2015; American Society of Civil Engineers: Reston, VA, USA, 2015; pp. 1-12.

44. Ramanayaka, C.D.D.; Venkatachalam, S. Reflection on BIM Development Practices at the Pre-maturity. Procedia Eng. 2015, 123, 462-470. [CrossRef]

45. Ma, Z.; Wei, Z.; Zhang, X. Semi-automatic and specification-compliant cost estimation for tendering of building projects based on IFC data of design model. Autom. Constr. 2013, 30, 126-135. [CrossRef]

46. Niknam, M.; Karshenas, S. Integrating distributed sources of information for construction cost estimating using Semantic Web and Semantic Web Service technologies. Autom. Constr. 2014, 57, 222-238. [CrossRef]

47. Abanda, F.H.; Kamsu-Foguem, B.; Tah, J.H.M. BIM - New Rules of Measurement ontology for construction cost estimation. Eng. Sci. Technol. Int. J. 2017. [CrossRef]

48. Shen, Z.; Issa, R. QUANTITATIVE EVALUATION OF THE BIM-ASSISTED CONSTRUCTION DETAILED COST ESTIMATES. Pap. Constr. Manag. 2010, 15, 234-257.

49. Choi, J.; Kim, H.; Kim, I. Open BIM-based quantity take-off system for schematic estimation of building frame in early design stage. J. Comput. Des. Eng. 2015, 2, 16-25. [CrossRef]

50. Olsen, D.; Taylor, J.M. Quantity Take-Off Using Building Information Modeling (BIM), and Its Limiting Factors. Procedia Eng. 2017, 196, 1098-1105. [CrossRef] 
51. Sigalov, K.; König, M. Recognition of process patterns for BIM-based construction schedules. Adv. Eng. Inform. 2017, 33, 456-472. [CrossRef]

52. Liu, H.; Al-Hussein, M.; Lu, M. BIM-based integrated approach for detailed construction scheduling under resource constraints. Autom. Constr. 2015, 53, 29-43. [CrossRef]

53. Wang, K.C.; Wang, W.C.; Wang, H.H.; Hsu, P.Y.; Wu, W.H.; Kung, C.J. Applying building information modeling to integrate schedule and cost for establishing construction progress curves. Autom. Constr. 2016, 72, 397-410. [CrossRef]

54. Zhiliang, M.; Zhenhua, W.; Wu, S.; Zhe, L. Application and extension of the IFC standard in construction cost estimating for tendering in China. Autom. Constr. 2011, 20, 196-204. [CrossRef]

55. Kehily, D.; Woods, T. Linking Effective Whole Life Cycle Cost Data to Parametric Building Information Models Using BIM Technologies Requirements to Parametric Building Information Models Using BIM Technologies. CITA BIM Gather. 2013, 2013, 1-9.

56. Guo, F.; Chang-Richards, Y.; Wilkinson, S.; Li, T.C. Effects of project governance structures on the management of risks in major infrastructure projects: A comparative analysis. Int. J. Proj. Manag. 2014, 32, 815-826. [CrossRef]

57. British Standard Institution (BSI). PAS 1192-3:2014-Specification for Information Management for the Operational Phase of Assets Using Building Information Modelling; British Standard Institute: British Standard Limited: London, UK, 2014; pp. 1-44.

58. Abanda, F.H.; Tah, J.H.M.; Keivani, R. Trends in built environment Semantic Web applications: Where are we today? Expert Syst. Appl. 2013, 40, 5563-5577. [CrossRef]

59. Golbreich, C. Combining Rule and Ontology Reasoners for the Semantic Web BT - Rules and Rule Markup Languages for the Semantic Web. In Proceedings of the Third International Workshop, RuleML 2004, Hiroshima, Japan, 8 November 2004; Antoniou, G., Boley, H., Eds.; Springer: Berlin/Heidelberg, Germany, 2004; pp. 6-22.

60. Hitzler, P.; Krotzsch, M.; Rudolph, S. Foundations of Semantic Web Technologies; Chapman \& Hall/CRC Textbooks in Computing; Taylor \& Francis: Abingdon-on-Thames, UK, 2009; ISBN 9781420090505.

61. Karan, E.P.; Irizarry, J. Extending BIM interoperability to preconstruction operations using geospatial analyses and semantic web services. Autom. Constr. 2015, 53, 1-12. [CrossRef]

62. Pauwels, P.; Zhang, S.; Lee, Y. Semantic web technologies in AEC industry: A literature overview. Autom. Constr. 2015, 73, 145-165. [CrossRef]

63. Mignard, C.; Nicolle, C. Merging BIM and GIS using ontologies application to Urban facility management in ACTIVe3D. Comput. Ind. 2014, 65, 1276-1290. [CrossRef]

64. Wetzel, E.M.; Thabet, W.Y. The use of a BIM-based framework to support safe facility management processes. Autom. Constr. 2015, 60, 12-24. [CrossRef]

65. Hou, S. An Ontology-Based Holistic Approach for Multi-Objective Sustainable Structural Design. Ph.D. Thesis, Cardiff University, Cardiff, UK, 2015.

66. Zhang, S.; Boukamp, F.; Teizer, J. Ontology-based semantic modeling of construction safety knowledge: Towards automated safety planning for job hazard analysis (JHA). Autom. Constr. 2015, 52, 29-41. [CrossRef]

67. Tomašević, N.M.; Batić, M.; Blanes, L.M.; Keane, M.M.; Vraneš, S. Ontology-based facility data model for energy management. Adv. Eng. Inform. 2015, 29, 971-984. [CrossRef]

68. Cheung, F.K.T.; Rihan, J.; Tah, J.; Duce, D.; Kurul, E. Early stage multi-level cost estimation for schematic BIM models. Autom. Constr. 2012, 27, 67-77. [CrossRef]

69. Lee, S.-K.; Kim, K.-R.; Yu, J.-H. BIM and ontology-based approach for building cost estimation. Autom. Constr. 2014, 41, 96-105. [CrossRef]

70. Tserng, H.P.; Yin, S.Y.L.; Dzeng, R.J.; Wou, B.; Tsai, M.D.; Chen, W.Y. A study of ontology-based risk management framework of construction projects through project life cycle. Autom. Constr. 2009, 18, 994-1008. [CrossRef]

71. Ding, L.Y.; Zhong, B.T.; Wu, S.; Luo, H.B. Construction risk knowledge management in BIM using ontology and semantic web technology. Saf. Sci. 2016, 87, 202-213. [CrossRef]

72. Gao, X.; Pishdad-Bozorgi, P. BIM-enabled facilities operation and maintenance: A review. Adv. Eng. Inform. 2019, 39, 227-247. [CrossRef]

73. Heaton, J.; Parlikad, A.K.; Schooling, J. Design and development of BIM models to support operations and maintenance. Comput. Ind. 2019, 111, 172-186. [CrossRef] 
74. Pishdad-Bozorgi, P.; Gao, X.; Eastman, C.; Self, A.P. Planning and developing facility management-enabled building information model (FM-enabled BIM). Autom. Constr. 2018, 87, 22-38. [CrossRef]

75. Aziz, N.D.; Nawawi, A.H.; Ariff, N.R.M. Building Information Modelling (BIM) in Facilities Management: Opportunities to be Considered by Facility Managers. Procedia Soc. Behav. Sci. 2016, 234, 353-362. [CrossRef]

76. Porwal, A.; Hewage, K.N. Building Information Modeling (BIM) partnering framework for public construction projects. Autom. Constr. 2013, 31, 204-214. [CrossRef]

77. HM Government. 3-Digital Built Britain Level 3 Building Information Modelling-Strategic Plan; UK Government: London, UK, 2015; pp. 1-47.

78. Motawa, I.; Carter, K. Sustainable BIM-based Evaluation of Buildings. Procedia Soc. Behav. Sci. 2013, 74, 419-428. [CrossRef]

79. Grilo, A.; Jardim-Goncalves, R. Challenging electronic procurement in the AEC sector: A BIM-based integrated perspective. Autom. Constr. 2011, 20, 107-114. [CrossRef]

(C) 2020 by the authors. Licensee MDPI, Basel, Switzerland. This article is an open access article distributed under the terms and conditions of the Creative Commons Attribution (CC BY) license (http://creativecommons.org/licenses/by/4.0/). 